Prepared in cooperation with the Indiana Department of Transportation

\title{
Flood-Inundation Maps for the Patoka River in and near Jasper, Southwestern Indiana
}

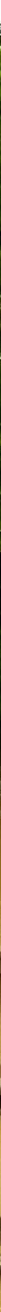

Scientific Investigations Report 2017-5138

U.S. Department of the Interior

U.S. Geological Survey 
Cover: Photo of flooding downstream of Third Avenue showing the River Walk and the pedestrian bridge, at Jasper, Indiana, May 1, 2017. (Photograph by Jeff Sallas, U.S. Geological Survey)

Back cover: Photo of flooding at the Jasper City Mill and the pedestrian bridge at Third Avenue, at Jasper, Indiana, May 1, 2017. (Photograph by Jeff Sallas, U.S. Geological Survey) 


\section{Flood-Inundation Maps for the Patoka River in and near Jasper, Southwestern Indiana}

By Kathleen K. Fowler

Prepared in cooperation with the

Indiana Department of Transportation

Scientific Investigations Report 2017-5138 


\title{
U.S. Department of the Interior \\ RYAN K. ZINKE, Secretary
}

\section{U.S. Geological Survey William H. Werkheiser, Deputy Director exercising the authority of the Director}

\author{
U.S. Geological Survey, Reston, Virginia: 2018
}

For more information on the USGS - the Federal source for science about the Earth, its natural and living resources, natural hazards, and the environment-visit https://www.usgs.gov or call 1-888-ASK-USGS.

For an overview of USGS information products, including maps, imagery, and publications, visit https://store.usgs.gov.

Any use of trade, firm, or product names is for descriptive purposes only and does not imply endorsement by the U.S. Government.

Although this information product, for the most part, is in the public domain, it also may contain copyrighted materials as noted in the text. Permission to reproduce copyrighted items must be secured from the copyright owner.

Suggested citation:

Fowler, K.K., 2018, Flood-inundation maps for the Patoka River in and near Jasper, southwestern Indiana: U.S. Geological Survey Scientific Investigations Report 2017-5138, 11 p., https://doi.org/10.3133/sir20175138.

ISSN 2328-0328 (online) 


\section{Acknowledgments}

The author wishes to thank the U.S. Army Corps of Engineers-Louisville District for cooperating in the funding for the operation and maintenance of the streamgage used for this study. Special thanks are given to the Indiana Department of Transportation for their cooperation in this study and to the National Weather Service for their continued support to the U.S. Geological Survey flood-inundation mapping initiative. 



\section{Contents}

\begin{tabular}{|c|}
\hline Purpose and Scope .................. \\
\hline Study Area Description.......... \\
\hline Previous Studies ......................................... \\
\hline reation of Flood-Inundation Map Library \\
\hline 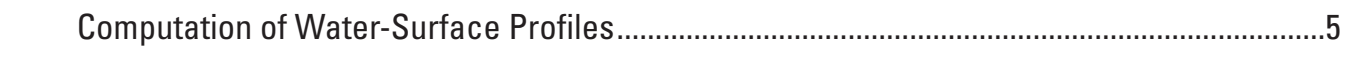 \\
\hline 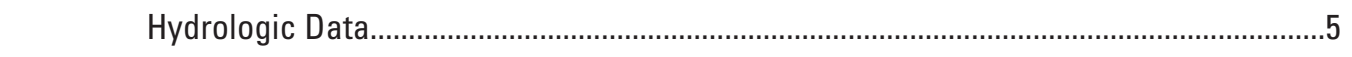 \\
\hline Topographic and Bathymetric Data \\
\hline Hydraulic Structures \\
\hline Energy-Loss Factors \\
\hline 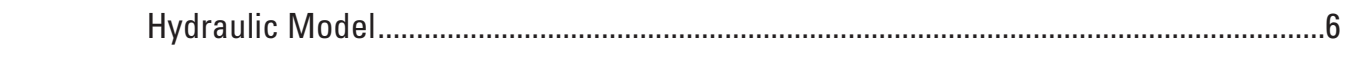 \\
\hline Development of Water-Surface Profiles \\
\hline 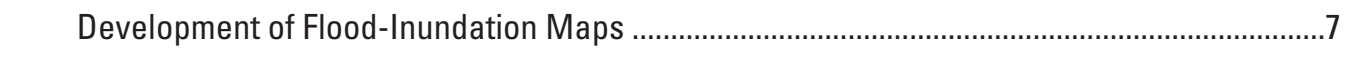 \\
\hline Flood-Inundation Map Delivery \\
\hline 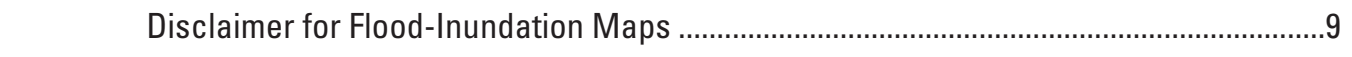 \\
\hline Uncertainties and Limitations Regarding Use of Flood-Inundation Maps ........................9 \\
\hline
\end{tabular}




\section{Figures}

1. Map showing locations of study reach for the Patoka River in and near Jasper, southwestern Indiana; U.S. Geological Survey streamgage Patoka River at Jasper (station number 03375500); and National Weather Service forecast site (JPRI3)

2. Map showing flood-inundation map for the Patoka River in and near Jasper, Indiana, corresponding to a stage of 19.0 feet at the U.S. Geological Survey streamgage Patoka River at Jasper, Indiana (station number 03375500)

\section{Tables}

1. U.S. Geological Survey streamgage information for the Patoka River at Jasper, Indiana (station number 03375500)

2. Discharges for selected annual exceedance probabilities for the Patoka River at Jasper, Indiana (U.S. Geological Survey station number 03375500)

3. Estimated discharges for corresponding stages and water-surface elevations at the U.S. Geological Survey streamgage on the Patoka River at Jasper, Indiana (station number 03375500).

4. Calibration of hydraulic model to target water-surface elevations for stages $\mathbf{1 5 . 0}$ to $19.0 \mathrm{ft}$ at the U.S. Geological Survey streamgage on the Patoka River at Jasper, Indiana (station number 03375500)

5. Calibration of hydraulic model to high-water mark elevations at selected locations along the Patoka River in Jasper, Indiana, for the flood of April 30, 2017. 


\section{Conversion Factors}

U.S. customary units to International System of Units

\begin{tabular}{|c|c|c|}
\hline Multiply & By & To obtain \\
\hline \multicolumn{3}{|c|}{ Length } \\
\hline foot $(\mathrm{ft})$ & 0.3048 & meter $(\mathrm{m})$ \\
\hline mile (mi) & 1.609 & kilometer (km) \\
\hline \multicolumn{3}{|c|}{ Area } \\
\hline square mile $\left(\mathrm{mi}^{2}\right)$ & 2.590 & square kilometer $\left(\mathrm{km}^{2}\right)$ \\
\hline \multicolumn{3}{|c|}{ Volume } \\
\hline acre-foot (acre-ft) & 1,233 & $\operatorname{meter}^{3}\left(\mathrm{~m}^{3}\right)$ \\
\hline \multicolumn{3}{|c|}{ Flow rate } \\
\hline cubic foot per second $\left(\mathrm{ft}^{3} / \mathrm{s}\right)$ & 0.02832 & cubic meter per second $\left(\mathrm{m}^{3} / \mathrm{s}\right)$ \\
\hline \multicolumn{3}{|c|}{ Hydraulic gradient } \\
\hline foot per mile (ft/mi) & 0.1894 & meter per kilometer $(\mathrm{m} / \mathrm{km})$ \\
\hline
\end{tabular}

Vertical coordinate information is referenced to (1) stage, the height above an arbitrary datum established at a streamgage, and (2) elevation, the height above the North American Vertical Datum of 1988 (NAVD 88).

Horizontal coordinate information is referenced to the North American Datum of 1983 (NAD 83). 



\title{
Flood-Inundation Maps for the Patoka River in and near Jasper, Southwestern Indiana
}

\author{
By Kathleen K. Fowler
}

\section{Abstract}

Digital flood-inundation maps for a 9.5-mile reach of the Patoka River in and near the city of Jasper, southwestern Indiana (Ind.), from the streamgage near County Road North 175 East, downstream to State Road 162, were created by the U.S. Geological Survey (USGS) in cooperation with the Indiana Department of Transportation. The flood-inundation maps, which can be accessed through the USGS Flood Inundation Mapping Science web site at https://water.usgs.gov/ osw/flood_inundation/, depict estimates of the areal extent and depth of flooding corresponding to selected water levels (stages) at the USGS streamgage Patoka River at Jasper, Ind. (station number 03375500). The Patoka streamgage is located at the upstream end of the 9.5-mile river reach. Near-real-time stages at this streamgage may be obtained from the USGS National Water Information System at https://waterdata.usgs. gov/ or the National Weather Service Advanced Hydrologic Prediction Service at http://water.weather.gov/ahps/, although flood forecasts and stages for action and minor, moderate, and major flood stages are not currently (2017) available at this site (JPRI3).

Flood profiles were computed for the stream reach by means of a one-dimensional step-backwater model. The hydraulic model was calibrated by using the most current stage-discharge relation at the Patoka River at Jasper, Ind., streamgage and the documented high-water marks from the flood of April 30, 2017. The calibrated hydraulic model was then used to compute five water-surface profiles for flood stages referenced to the streamgage datum ranging from 15 feet (ft), or near bankfull, to $19 \mathrm{ft}$. The simulated water-surface profiles were then combined with a geographic information system digital elevation model (derived from light detection and ranging [lidar] data having a $0.98 \mathrm{ft}$ vertical accuracy and $4.9 \mathrm{ft}$ horizontal resolution) to delineate the area flooded at each water level.

The availability of these flood-inundation maps, along with real-time stage from the USGS streamgage at the Patoka River at Jasper, Ind., will provide emergency management personnel and residents with information that is critical for flood response activities such as evacuations and road closures as well as for postflood recovery efforts.

\section{Introduction}

The city of Jasper in Bainbridge Township, Dubois County, in southwestern Indiana (Ind.) (fig. 1), has an estimated population of 15,038 (U.S. Census Bureau, 2010). Jasper and the surrounding area have experienced flooding numerous times, most recently in 2006, 2008, 2011, 2014, and 2017 (U.S. Geological Survey [USGS], 2017d). The majority of flood damages in the Jasper area have occurred along the Patoka River to the north and south of the city (Federal Emergency Management Agency [FEMA], 2014). Since the construction of the Patoka Lake Dam was completed and began storing water in February 1978, approximately 26 miles (mi) upstream of the study area, flooding problems have declined. The Patoka Lake Dam is an earth- and rockfilled dam 1,550 feet (ft) long and $84 \mathrm{ft} \mathrm{high}$. The lake has a storage capacity at the spillway crest (elevation $548 \mathrm{ft}$ ) of 298,380 acres per foot (FEMA, 2014). The city of Jasper has protection from flooding by the Patoka Lake Dam, which is a U.S. Army Corps of Engineers (USACE) flood-control structure. However, businesses and residential property close to the river can still be affected by flooding. As the river stage rises, portions of some local roads (Third Avenue, Second Street, and Clay Street) are impassable. A low-lying area to the north and east of Jasper called Buffalo Flat also experiences flooding during high flows. In addition, agricultural lands south of the city have potential for flooding as embankments are overtopped. Flood plains along the river are moderately developed and contain a mix of residential, commercial, and agricultural areas.

Prior to this study, emergency responders in Jasper relied on several information sources to make decisions on how to best alert the public and mitigate flood damages. One source is the FEMA flood insurance study (FIS) for Dubois County (FEMA, 2014). A second source of information is the USGS streamgage, Patoka River at Jasper, Ind. (03375500), hereafter referred to as the Jasper streamgage. The web site from which current and historical (USGS, 2017c) water levels (stage) and discharges can be obtained for the USGS streamgage, Patoka River at Jasper, Ind. (03375500) is https://nwis.waterdata. usgs.gov/in/nwis/inventory/?site_no $=03375500 \& a g e n c y$ cd=USGS. A third source is the National Weather Service (NWS) Advanced Hydrologic Prediction Service's (AHPS) 


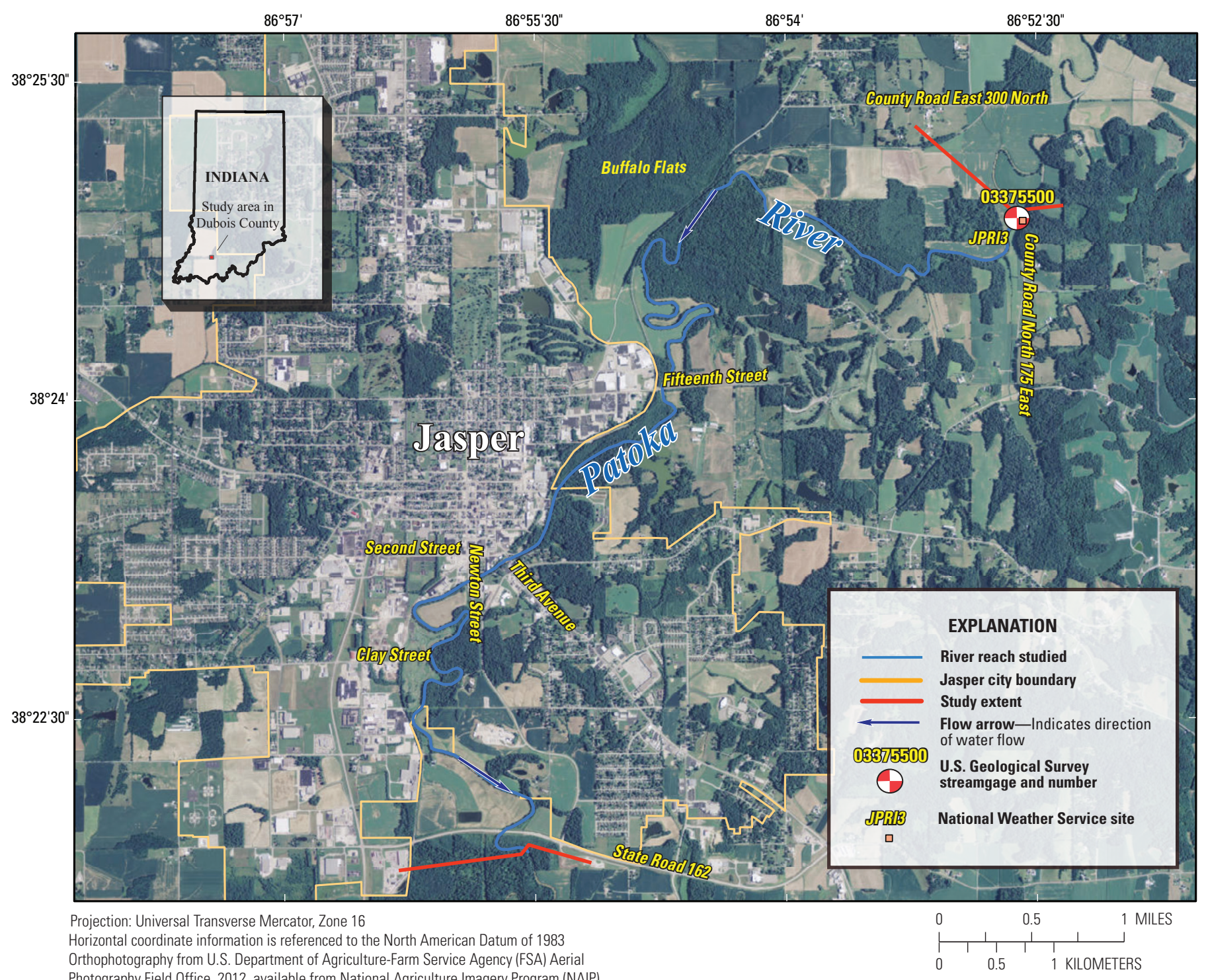

Figure 1. Locations of study reach for the Patoka River in and near Jasper, southwestern Indiana; U.S. Geological Survey streamgage Patoka River at Jasper (station number 03375500); and National Weather Service forecast site (JPRI3).

web site for the streamgage (JPRI3), which displays only the observed stage from the Jasper streamgage (NWS, 2017). The NWS AHPS web site for JPRI3 does not provide a flood forecast as at some other NWS AHPS sites.

Although the current stage at the Jasper streamgage is particularly useful for residents in the immediate vicinity of a streamgage, it is of limited use to residents farther upstream or downstream because the water-surface elevation is not constant along the entire stream reach. Knowledge of a stage at a streamgage is difficult to translate into depth and areal extent of flooding at points distant from the streamgage. One way to address these informational gaps is to produce a library of flood-inundation maps that are referenced to the stages recorded at a USGS streamgage. By referring to the appropriate map, emergency responders can discern the severity of flooding (depth of water and areal extent); identify roads that are, or will soon be, flooded; and make plans for the notification or evacuation of residents in harm's way for some distance upstream and downstream from the streamgage. In addition, the capability to visualize the potential extent of flooding has been shown to motivate residents to take precautions and heed warnings that they previously might have disregarded. In 2016-17, the USGS, in cooperation with the Indiana Department of Transportation, conducted a project to produce a library of flood-inundation maps for the Patoka River at and near Jasper. 


\section{Purpose and Scope}

This report describes the development of a series of estimated flood-inundation maps for the Patoka River at and near Jasper and identifies where maps can be accessed on the web and ancillary data (geographic information system [GIS] flood polygons and depth grids) can be downloaded. Web users can select estimated inundation maps that correspond to (1) flood stages at the Jasper streamgage (03375500) and (2) the NWS AHPS site JPRI3. The scope of the study was limited to a 9.5-mi reach of the Patoka River starting at the streamgage located just west of County Road North 175 East (fig. 1).

The flood-inundation maps were produced for flood levels referenced to the stage recorded at streamgage 03375500 (table 1); the streamgage is on the east bank of the Patoka River near County Road North 175 East. The maps cover a range in stage from 15 to $19 \mathrm{ft}$. The 15 -ft stage is approximately bankfull, and the 19-ft stage is about $1.2 \mathrm{ft}$ higher than the highest recorded stage since the upstream Patoka Lake Dam (not shown) was completed in February 1978. Since the regulation of flow in the river by operations at the Patoka Lake Dam started in 1978, the highest stage was $17.83 \mathrm{ft}$ at the Jasper streamgage on March 19, 2008. Before completion of the dam in February 1978, the highest stage at the streamgage was $21.2 \mathrm{ft}$ in March of 1964 (U.S. Geological Survey, 2017d).

\section{Study Area Description}

The Patoka River near the city of Jasper is in southwest Indiana at the western edge of the Crawford Upland physiographic section of the Southern Hills and Lowlands Region (Gray, 2000). The study reach starts at the Patoka River at Jasper streamgage about $1.3 \mathrm{mi}$ downstream of the County Road E300N bridge (near its intersection with County Road N175E) and about $25 \mathrm{ft}$ west of County Road N175E on the east bank of the river (fig. 1). The study reach ends $9.5 \mathrm{mi}$ downstream on the downstream side of the State Road 162 bridge. The drainage area is 262 square miles $\left(\mathrm{mi}^{2}\right)$ at the upstream end of the study reach at the Jasper streamgage (USGS, 2017c) and $278 \mathrm{mi}^{2}$ at the downstream end of the study reach (USGS, $2017 b)$. The headwaters of the Patoka River originate in Orange County, Ind. (not shown) adjacent and northeast of Dubois County (not shown), and the river flows generally southwestward. As the river passes the northeast edge of the city, it is flowing to the southwest. Within the study reach, the Patoka River has only minor tributaries: Jasper Brook, Part Brook, Plain Drain, Cline Brook, Calumet Run/Buffalo Stream, Silt Run, and Ditch Branch (not shown).

Generally, the Jasper area has bedrock hills of high relief (Gray, 2000). The study reach is approximately $9.5 \mathrm{mi}$ long, has an average top-of-bank channel width of about $104 \mathrm{ft}$, and has an average channel slope of 0.0003 (1.5 feet per mile). Much of the land contiguous to the study reach to the northeast of Jasper is agricultural and forested. The city of Jasper is on the west side of the river with businesses, industry, and residences. South of the city, the land contiguous to the study reach is made up of agriculture, forest, industry, a golf course, and some homes.

The population of Jasper has increased in recent years from 15,038 in 2010 (U.S. Census Bureau, 2010) to 15,451 in 2015 (U.S. Census Bureau, 2015). According to the U.S.

Census Bureau, the city has a total area of $13.1 \mathrm{mi}^{2}$. The main channel of the Patoka River and adjacent flood plain within the study reach have four major road crossings: Fifteenth Street, Third Avenue, Newton Street, and State Road 162 (fig. 1). A low-head dam is located approximately $10 \mathrm{ft}$ downstream of the Third Avenue/State Road 164 bridge, and pedestrian bridges are located about $175 \mathrm{ft}$ downstream of the Third Avenue/State Road 164 bridge and about 2,000-ft downstream of Newton Street bridge.

Table 1. U.S. Geological Survey streamgage information for the Patoka River at Jasper, Indiana (station number 03375500).

[mi², square miles; ', degree; ', minutes; ", seconds; NAD 83, North American Datum of 1983; NAVD 88, North American Vertical Datum of 1988; ft, feet; $\mathrm{ft}^{3} / \mathrm{s}$, cubic feet per second]

\begin{tabular}{|c|c|c|c|c|c|c|c|c|c|}
\hline $\begin{array}{c}\text { Streamgage } \\
\text { name }\end{array}$ & $\begin{array}{c}\text { Streamgage } \\
\text { number }\end{array}$ & $\begin{array}{c}\text { Drainage } \\
\text { area } \\
\left(\mathrm{mi}^{2}\right)\end{array}$ & $\begin{array}{l}\text { Latitude } \\
\text { (NAD 83) }\end{array}$ & $\begin{array}{l}\text { Longitude } \\
\text { (NAD 83) }\end{array}$ & $\begin{array}{l}\text { Period of } \\
\text { record }\end{array}$ & $\begin{array}{c}\text { Datum of } \\
\text { streamgage } \\
\text { (NAVD 88) }\end{array}$ & $\begin{array}{l}\text { Maximum } \\
\text { recorded flood } \\
\text { elevation } \\
\text { (NAVD 88) } \\
\text { and date }\end{array}$ & $\begin{array}{l}\text { Maximum } \\
\text { discharge } \\
\left(\mathrm{ft}^{3} / \mathrm{s}\right) \text { dur- } \\
\text { ing period } \\
\text { of record, } \\
\text { and date }\end{array}$ & $\begin{array}{c}\text { Maximum } \\
\text { discharge }\left(\mathrm{ft}^{3} / \mathrm{s}\right) \\
\text { after regulation' } \\
\text { by the Patoka } \\
\text { Lake Dam, } \\
\text { and date }\end{array}$ \\
\hline $\begin{array}{l}\text { Patoka } \\
\text { River at } \\
\text { Jasper, } \\
\text { Indiana }\end{array}$ & 03375500 & 262 & $38^{\circ} 24^{\prime} 49^{\prime \prime}$ & $86^{\circ} 52^{\prime} 36^{\prime \prime}$ & $\begin{array}{c}\text { November } \\
1947 \text { to } \\
\text { present } \\
(2017)\end{array}$ & $445.22 \mathrm{ft}$ & $\begin{array}{l}466.42 \mathrm{ft} \text { on } \\
\text { March } 11, \\
1964 \text { (cor- } \\
\text { responds to } \\
\text { a stage of } \\
21.2 \mathrm{ft})\end{array}$ & $\begin{array}{l}\text { 14,100, } \\
\text { March 11, } \\
1964\end{array}$ & $\begin{array}{l}7,130, \\
\text { March } 19, \\
2008 \text { (cor- } \\
\text { responds to } \\
\text { a stage of } \\
17.83 \mathrm{ft})\end{array}$ \\
\hline
\end{tabular}

${ }^{1}$ Regulation of the Patoka River downstream of the Patoka Lake Dam began in February 1978. 


\section{Previous Studies}

The most recent FEMA FIS that provides information for the study area near the Patoka River at Jasper is for Dubois County (FEMA, 2014) and covers the geographic area of Dubois County, Ind., including the incorporated community of Jasper. The hydrologic and hydraulic analysis for the study was performed by Morley \& Associates, Inc. during 2004 to 2005 for the Federal Insurance Administration under agreement number EMC-2005-GR-7022. The FIS for Dubois County did not become effective until October 16, 2014.

FEMA has produced Digital Flood Insurance Rate Maps that include the study area in Dubois County (FEMA, 2017). The Digital Flood Insurance Rate Maps outline the special flood hazard areas for the 1-percent annual flood around Patoka River. In addition, the Indiana Department of Natural Resources, the USGS, the Natural Resources Conservation Service, and the USACE have agreed to the values for discharge-frequency for sites along many rivers in Indiana; the values are termed "coordinated" discharges and assure consistency among the State and Federal agencies that undertake streamflow studies (Indiana Department of Natural Resources, 1976). The coordinated discharges for the Patoka River at the Jasper streamgage were obtained from the Indiana Department of Natural Resources (2017) and the USGS StreamStats Program for Indiana Streams (USGS, 2017b) and are listed in table 2. Knipe and Rao (2005) published peak flow statistics for many Indiana streams. Those statistics, along with those computed from the USGS PeakFQ computer program (Flynn and others, 2006), are listed in table 2. Table 2 compares three different time periods for calculating the peak flows. The PeakFQ uses only the water year discharges that were considered unregulated flows.

\section{Creation of Flood-Inundation Map Library}

The USGS has standardized the procedures for creating flood-inundation maps for flood-prone communities so that the process followed and products produced are similar regardless of which USGS office is responsible for the work (USGS, 2017a). Tasks specific to the development of the flood maps for Jasper, Ind. were (1) collection of topographic and bathymetric data for selected cross sections and geometric data for the Fifteenth Street, Third Avenue, Newton Street, and State Road 162 bridges; a low-head dam; and two pedestrian bridges; (2) estimation of energy-loss factors (roughness coefficients) in the stream channel and flood plain and determination of steady-flow data; (3) computation of water-surface profiles using the USACE Hydrologic Engineering Center's River Analysis System (HEC-RAS) computer program (USACE, 2016); (4) production of estimated flood-inundation maps at various river stages using the USACE HEC-GeoRAS computer program (USACE, 2011) and a GIS computer program called ArcGIS (Esri, 2014); and (5) preparation of the maps, both as shapefile polygons that depict the areal extent of flood inundation and as depth grids that provide the depth of floodwaters, for display on a USGS flood-inundation mapping

Table 2. Discharges for selected annual exceedance probabilities for the Patoka River at Jasper, Indiana (U.S. Geological Survey station number 03375500).

[-, not calculated; $\mathrm{ft}^{3} / \mathrm{s}$, cubic feet per second; USGS, U.S. Geological Survey]

\begin{tabular}{|c|c|c|c|}
\hline $\begin{array}{c}\text { Annual } \\
\text { exceedance } \\
\text { probability } \\
\text { (AEP) (percent) }\end{array}$ & $\begin{array}{c}\text { Coordinated peak flows }{ }^{1}\left(\mathrm{ft}^{3} / \mathrm{s} \text { ) }\right. \\
\text { for } 34 \text { years (water years 1913, } \\
1937 \text {, and } 1948 \text { to 1979) }\end{array}$ & $\begin{array}{c}\text { Peak flows }\left(\mathrm{ft}^{3} / \mathrm{s}\right) \text { for } 58 \text { years } \\
\text { (water years 1913, 1937, } \\
\text { and } 1948 \text { to 2003) }\end{array}$ & $\begin{array}{c}\text { Peak flows }\left(\mathrm{ft}^{3} / \mathrm{s} \text { ) from USGS }\right. \\
\text { PeakF0 peak flow analyses }{ }^{3} \text { for } \\
37 \text { years using WY } 1979 \text { to } 2015 \\
\text { (regulated period - since completion } \\
\text { of Patoka Lake Dam) }\end{array}$ \\
\hline 50 & - & - & 2,420 \\
\hline 10 & 9,560 & 9,030 & 4,430 \\
\hline 4 & 12,200 & 12,600 & 5,610 \\
\hline 2 & 15,200 & 15,700 & 6,570 \\
\hline 1 & 18,000 & 19,200 & 7,610 \\
\hline
\end{tabular}

${ }^{1}$ Data from the StreamStats Program (U.S. Geological Survey, 2014b).

${ }^{2}$ From Knipe and Rao (2005).

${ }^{3}$ From Flynn and others (2006). 
application (https://wimcloud.usgs.gov/apps/FIM/FloodInundationMapper.html).

\section{Computation of Water-Surface Profiles}

The water-surface profiles used to produce the five flood-inundation maps in this study were simulated by using HEC-RAS, version 5.0.0 (USACE, 2016). HEC-RAS is a one-dimensional step-backwater model for simulation of water-surface profiles with steady-state (gradually varied) or unsteady-state flow computation options. The HEC-RAS analysis for this study was done using the steady-state (gradually varied) flow computation option.

\section{Hydrologic Data}

The study reach consists of one USGS streamgage, Patoka River at Jasper, Ind. (03375500; fig. 1; table 1) that has been in operation since November 1947. This streamgage has a continuous record of measured river water level (stage) and computed streamflow. Stage is measured every 15 minutes, transmitted hourly via satellite from the streamgage, and made available on the web through the USGS National Water Information System (NWIS; USGS, 2017e). Stage data from this streamgage are referenced to a local gage datum, but the data can be converted to water-surface elevations referenced to the North American Vertical Datum of 1988 (NAVD 88) by adding $445.22 \mathrm{ft}$. Continuous records of streamflow are computed from a stage-discharge relation, which has been developed for the streamgage, and are available through the USGS NWIS web site (https://waterdata.usgs.gov/nwis).

The steady-flow data necessary for the hydraulic model consisted of boundary conditions (normal depth) and flooddischarge information. The floodflows used in the model simulations (table 3 ) were taken from the stage-discharge relation (USGS rating no. 36) for the Jasper streamgage and corresponded with the stages from 15 to $19 \mathrm{ft}$ in 1 - $\mathrm{ft}$ intervals. All computations used flood-discharge values for the select stages with the stage-discharge relation at the streamgage. No major tributaries join the Patoka River within the 9.5-mi study reach; therefore, the gage-derived discharges at the Jasper streamgage were not adjusted for tributary inflows but were held constant throughout the study reach for a given profile.

\section{Topographic and Bathymetric Data}

All topographic data used in this study are referenced vertically to NAVD 88 and horizontally to the North American Datum of 1983 (NAD 83). Cross-section elevation data were obtained from a digital elevation model (DEM) that was derived from light detection and ranging (lidar) data that were collected as part of a statewide project during 2011-13 by Woolpert, Inc. (2011). The lidar data for Dubois County were collected in 2013. The DEM was obtained from the Indiana Spatial Data Portal (Indiana University, 2013). The original lidar data have horizontal resolution of $4.9 \mathrm{ft}$ and vertical accuracy of $0.98 \mathrm{ft}$ at a 95 -percent confidence level based on a root mean squared error of $0.49 \mathrm{ft}$ for the "open terrain" land-cover category. By these criteria, the lidar data support production of 2-ft contours (Dewberry, 2012); the final DEM, which was resampled to a grid-cell size of $10 \mathrm{ft}$ by $10 \mathrm{ft}$ to decrease the GIS processing time, has a vertical accuracy of plus or minus $1 \mathrm{ft}$. By using HEC-GeoRAS (a set of procedures, tools, and utilities for processing geospatial data in ArcGIS), elevation data were extracted from the DEM for the land-surface portion of 52 cross sections. These data subsequently were input to the HEC-RAS model.

Because lidar data cannot provide ground elevations below a stream's water surface, channel cross sections were surveyed by USGS field crews during October 2016. Crosssectional depths were measured by using hydroacoustic

Table 3. Estimated discharges for corresponding stages and water-surface elevations at the U.S. Geological Survey streamgage on the Patoka River at Jasper, Indiana (station number 03375500).

[ft, feet; NAVD 88, North American Vertical Datum of 1988; ft³/s, cubic feet per second; USGS, U.S. Geological Survey]

\begin{tabular}{|c|c|c|}
\hline $\begin{array}{l}\text { Stage of water-surface profile }{ }^{1} \\
(\mathrm{ft})\end{array}$ & $\begin{array}{l}\text { Water-surface elevation } \\
\text { (ft, NAVD 88) }\end{array}$ & $\begin{array}{c}\text { Estimated discharge }{ }^{2} \text { at USGS } \\
\text { streamgage number } 03375500 \\
\left(\mathrm{ft}^{3} / \mathrm{s}\right)\end{array}$ \\
\hline 16 & 461.22 & 3,427 \\
\hline 18 & 463.22 & 7,599 \\
\hline 19 & 464.22 & 10,860 \\
\hline
\end{tabular}

\footnotetext{
${ }^{1}$ Water-surface profiles are 1-foot increments of stage, referenced to the gage datum of the U.S. Geological Survey streamgage, Patoka River at Jasper, Indiana (station 03375500).

${ }^{2}$ Discharge from USGS rating number 36.0.
} 
instrumentation (acoustic Doppler current profiler-ADCP) at 52 locations. A differential global positioning system with real-time kinematic technology was used to derive horizontal locations and the elevation of the water surface at each surveyed cross section.

\section{Hydraulic Structures}

Five structures, consisting of four road crossings (Fifteenth Street, Third Avenue, Newton Street, and State Road 162) and a low-head dam (just downstream of Third Avenue bridge), have the potential to affect water-surface elevations during floods along the river. The Fifteenth Street bridge is the most upstream of the hydraulic structures but almost 5 mi downstream of the Jasper streamgage. This bridge acts as a constriction that flattens the slope of the water-surface upstream of the structure. The two pedestrian bridges (downstream of Third Avenue bridge and Newton Street bridge) do not affect water-surface elevations. Bridgegeometry data were obtained from field surveys conducted by personnel from the USGS Indiana-Kentucky Water Science Center. It was determined from the surveys and the model that the pedestrian bridges would offer little obstruction to the flow of water due to their height and length. The highest flow modeled would not touch the low cord of either bridge, so they were not included with the four major bridges in the model. The low-head dam located immediately downstream of the Third Avenue bridge required special attention within the model. Because the dam is located so close to the bridge, it was not possible to model as an in-line structure. To do so caused the bridge exit section to be replaced by the dam dimensions. To ensure the effects of the dam were incorporated into the model, the dam elevations were inserted into the downstream internal-bridge cross section.

\section{Energy-Loss Factors}

Hydraulic analyses require the estimation of energy losses that result from frictional resistance exerted by a channel on flow. These energy losses are quantified by the
Manning's roughness coefficient ( $n$-value) (Arcement and Schneider, 1989). Initial (precalibration) $n$-values were selected on the basis of field observations and high-resolution aerial photographs. An $n$-value of 0.031 was selected for the main channel because it is natural, fairly clean, and low gradient. An $n$-value of 0.08 was used for the overbank areas, which are dominated by agricultural fields and forest in the rural sections of the study reach, and the residential and commercial areas of Jasper both north and south of the river.

The initial $n$-values were adjusted as part of the calibration process, which involved minimizing the differences between simulated and observed water-surface elevations at the streamgage and elsewhere along the study reach. Roughness-coefficient adjustment factors were varied by flow and adjusted until the simulated water-surface elevations approximated the target water-surface elevations (15- to 19-ft stages in 1-ft intervals at the Jasper streamgage). The final model $n$-values were computed by multiplying the initial $n$-value by each of the roughness-coefficient adjustment factors, and resulted in main channel $n$-values ranging from 0.025 to 0.038 , and overbank values ranging from 0.032 to 0.08 .

\section{Hydraulic Model}

The HEC-RAS analysis for this study was done using the steady-state flow computation option. Steady-state flow data consisted of flow regime, boundary conditions, and peak flows that produced water-surface elevations at the cross sections for the Jasper streamgage that matched target watersurface elevations (15- to 19 - $\mathrm{ft}$ stages) within $0.38 \mathrm{ft}$ of the rating for the streamgage (table 4 ). These target elevations coincided with even 1-ft increments of stage, referenced to the local streamgage datum. Subcritical (tranquil) flow regime was assumed for the simulations. Normal depth, based on an estimated average channel slope of 0.0003 from data obtained from the FEMA FIS flood profiles (FEMA, 2014) and the channel slope at the downstream end of the study reach, was used as the downstream boundary condition of the reach. The peak flows that were used in the model are discussed in the "Hydrologic Data" section.

Table 4. Calibration of hydraulic model to target water-surface elevations for stages 15.0 to $19.0 \mathrm{ft}$ at the U.S. Geological Survey streamgage on the Patoka River at Jasper, Indiana (station number 03375500).

[ft, feet; NAVD 88, North American Vertical Datum of 1988]

\begin{tabular}{cccc}
\hline $\begin{array}{c}\text { Stage of water-surface } \\
\text { profile } \\
\text { (ft) }\end{array}$ & $\begin{array}{c}\text { Target water-surface } \\
\text { elevation } \\
\text { (ft, NAVD 88) }\end{array}$ & $\begin{array}{c}\text { Simulated water-surface } \\
\text { elevation } \\
\text { (ft, NAVD 88) }\end{array}$ & $\begin{array}{c}\text { Elevation } \\
\text { difference } \\
\text { (ft) }\end{array}$ \\
\hline 15.00 & 460.22 & 460.25 & 0.03 \\
16.00 & 461.22 & 461.25 & 0.03 \\
17.00 & 462.22 & 462.12 & -0.10 \\
18.00 & 463.22 & 463.10 & -0.12 \\
19.00 & 464.22 & 464.60 & 0.38 \\
\hline
\end{tabular}


The hydraulic model was calibrated to the stage-discharge relation (rating 36.0) at the Jasper streamgage and to the documented high-water marks from the flood of April 30,2017 . The flood stage and discharge reached $17.33 \mathrm{ft}$ and 4,500 cubic feet per second, respectively, on April 30, 2017, at the streamgage. The flood discharge of 4,500 cubic feet per second is about a 10 percent annual exceedance probability floodflow. Model calibration was accomplished by adjusting Manning's $n$-values until the results of the hydraulic computations closely agreed with the observed water-surface elevations for given flows. Differences between target and simulated water-surface elevations for the five simulated flows at the Jasper streamgage were equal to or less than $0.38 \mathrm{ft}$ (table 4). Differences between surveyed and simulated elevations of high-water marks from the flood of April 30, 2017, were equal to or less than $0.65 \mathrm{ft}$ (table 5). The results demonstrate that the model is capable of simulating accurate water levels over a wide range of flows in the study reach.

\section{Development of Water-Surface Profiles}

The calibrated hydraulic model was used to generate water-surface profiles for a total of five stages at 1-ft intervals between $15 \mathrm{ft}$ and $19 \mathrm{ft}$ as referenced to the local datum of the Jasper streamgage. These stages correspond to elevations between $460.22 \mathrm{ft}$ and $464.22 \mathrm{ft}$, NAVD 88 .

\section{Development of Flood-Inundation Maps}

Flood-inundation maps were created in a GIS for the five water-surface profiles by combining the profiles and DEM data. The DEM data were derived from the same lidar data described previously in the "Topographic and Bathymetric Data" section and therefore have an estimated vertical accuracy of $2 \mathrm{ft}$ (that is, plus or minus $1 \mathrm{ft}$ ). Estimated flood-inundation boundaries for each simulated profile were developed with HEC-GeoRAS software (USACE, 2011), which allows the preparation of geometric data for import into HEC-RAS and processes simulation results exported from HEC-RAS (USACE, 2016). Shapefile polygons and depth grids of the inundated areas for each profile were modified, as required, in the ArcMap application of ArcGIS to ensure a hydraulically reasonable transition of the flood boundaries between modeled cross sections. The datasets used in this study are available through a data release at http://doi.org/10.5066/F7862DX0 (Fowler, 2017).

Any inundated areas that were detached from the main channel were examined to identify subsurface connections with the main river, such as through culverts under roadways. Where such connections existed, the mapped inundated areas were retained in their respective flood maps; otherwise, the erroneously delineated parts of the flood extent were deleted. The flood-inundation areas are overlaid on high-resolution, georeferenced, aerial photographs of the study area. Bridge surfaces are displayed as inundated regardless of the actual water-surface elevation in relation to the lowest structural chord of the bridge or the bridge deck.

Estimates of water depth can be obtained from the depthgrid data that are included with the presentation of the flood maps on an interactive USGS mapping application described in the following section, "Flood-Inundation Map Delivery." The flood-inundation map corresponding to the highest simulated water-surface profile, a stage of $19.0 \mathrm{ft}$, is presented in figure 2 .

Table 5. Calibration of hydraulic model to high-water mark elevations at selected locations along the Patoka River in Jasper, Indiana, for the flood of April 30, 2017.

[HWM, high-water mark; ft, feet; NAVD 88, North American Vertical Datum of 1988]

\begin{tabular}{|c|c|c|c|c|c|}
\hline Location & $\begin{array}{l}\text { High-water } \\
\text { mark identifier }\end{array}$ & $\begin{array}{l}\text { River } \\
\text { station } \\
(\mathrm{ft})^{1}\end{array}$ & $\begin{array}{c}\text { Surveyed } \\
\text { high-water } \\
\text { mark elevation } \\
(\mathrm{ft}, \mathrm{NAVD} 88)^{2}\end{array}$ & $\begin{array}{c}\text { Modeled } \\
\text { water-surface } \\
\text { elevation } \\
(\mathrm{ft}, \text { NAVD 88) }\end{array}$ & $\begin{array}{c}\text { Elevation } \\
\text { difference } \\
\text { (ft) }\end{array}$ \\
\hline Fifteenth Street & HWM 1 & 25,330 & 459.85 & 459.23 & -0.62 \\
\hline \multirow{2}{*}{ Third Avenue } & HWM1 & 17,087 & 457.60 & 456.95 & -0.65 \\
\hline & HWM3 & 17,686 & 457.81 & 457.21 & -0.60 \\
\hline \multirow{3}{*}{ Newton Street } & HWM1 & 16,581 & 457.14 & 456.87 & -0.27 \\
\hline & HWM2 & 16,581 & 457.16 & 456.87 & -0.29 \\
\hline & HWM3 & 16,336 & 457.06 & 456.81 & -0.25 \\
\hline
\end{tabular}

${ }^{1}$ River station references the distance upstream to the high-water mark from the most downstream point (starting point) in the hydraulic model.

${ }^{2}$ U.S. Geological Survey field survey of high-water marks for the flood of April 30, 2017.

${ }^{3}$ Elevation from hydraulic model profile. 


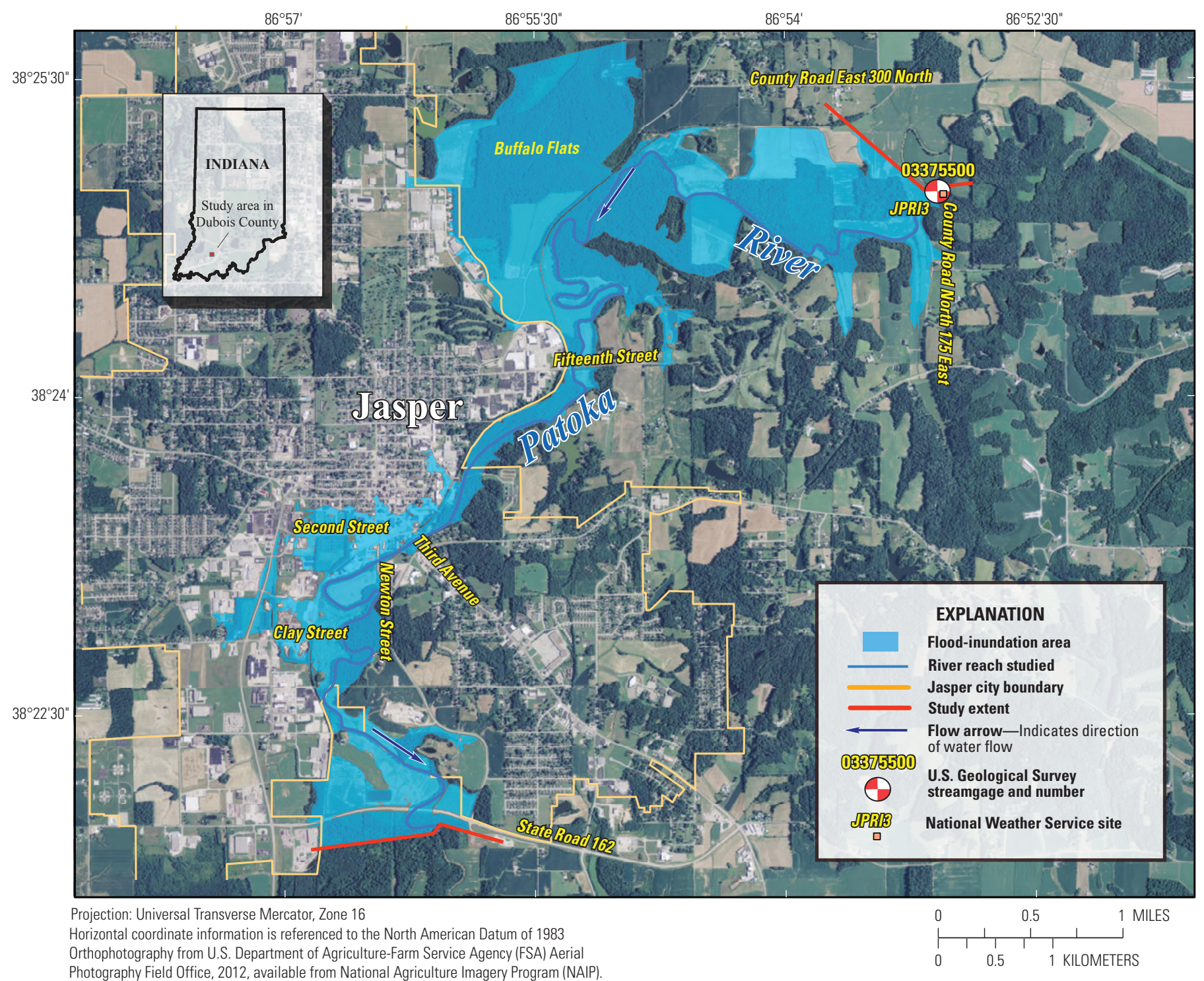

Figure 2. Flood-inundation map for the Patoka River in and near Jasper, Indiana, corresponding to a stage of 19.0 feet at the U.S. Geological Survey streamgage Patoka River at Jasper, Indiana (station number 03375500).

\section{Flood-Inundation Map Delivery}

The current study documentation is available online at the USGS Publications Warehouse (https://pubs.usgs.gov/sir/ 2017/5138). In addition, a Flood Inundation Mapping Science web site (https://wimcloud.usgs.gov/apps/FIM/FloodInundationMapper.html) (USGS, 2017b) has been established to make USGS flood-inundation study information available to the public; this Flood Inundation Mapping Science web site links to a mapping application that presents map libraries and provides detailed information on flood extents and depths for modeled sites. The mapping application enables the production of customized flood-inundation maps from the map library for the Patoka River at and near Jasper, Ind.
A link on this web site connects to the USGS NWIS (USGS, $2017 \mathrm{c}$ ), which presents the current stage and streamflow at USGS streamgage 03375500 to which the flood-inundation maps are referenced. A second link connects to the NWS AHPS site (NWS, 2017), so that the user can obtain applicable information on stage. The estimated flood-inundation maps are displayed in sufficient detail so that preparations for flooding and decisions for emergency response can be performed efficiently. Depending on the flood magnitude, roadways are shown as shaded (inundated and likely impassable) or not shaded (dry and passable) to facilitate emergency planning and use. Bridges are shaded - that is, shown as inundatedregardless of the flood magnitude. A shaded building should not be interpreted to indicate that the structure is completely 
submerged, rather that bare earth surfaces in the vicinity of the building are inundated. In these instances, the water depth (as indicated in the mapping application by holding the cursor over an inundated area) near the building would be an estimate of the water level inside the structure, unless flood-proofing measures had been implemented.

\section{Disclaimer for Flood-Inundation Maps}

The flood-inundation maps should not be used for navigation, regulatory, permitting, or other legal purposes. The USGS provides these maps "as is" for a quick reference, emergency planning tool but assumes no legal liability or responsibility resulting from the use of this information.

\section{Uncertainties and Limitations Regarding Use of Flood-Inundation Maps}

Although the flood-inundation maps represent the boundaries of inundated areas with a distinct line, some uncertainty is associated with these maps. The flood boundaries shown were estimated on the basis of water stages and streamflows at a selected USGS streamgage. Water-surface elevations along the stream reaches were estimated by steady-state hydraulic modeling, assuming unobstructed flow, and using streamflows and hydrologic conditions anticipated at the USGS streamgage. The hydraulic model reflects the land-cover characteristics and any bridge, embankment, or other hydraulic structures existing as of October 2016. Unique meteorological factors (timing and distribution of precipitation) may cause actual streamflows along the modeled reach to vary from those assumed during a flood, which may lead to deviations in the water-surface elevations and inundation boundaries shown. Additional areas may be flooded because of unanticipated conditions such as changes in the streambed elevation or roughness, backwater into major tributaries along a main stem river, blockage of water due to earthen embankments, or backwater from localized debris or ice jams. The accuracy of the floodwater extent portrayed on these maps will vary with the accuracy of the DEM used to simulate the land surface.

If this series of flood-inundation maps will be used in conjunction with NWS river forecasts, not currently (2017) available for the Jasper streamgage, the user should be aware of additional uncertainties that may be inherent or factored into NWS forecast procedures. The NWS uses forecast models to estimate the quantity and timing of water flowing through selected stream reaches in the United States. These forecast models (1) estimate the amount of runoff generated by precipitation and snowmelt, (2) simulate the movement of floodwater as it proceeds downstream, and (3) predict the flow and stage (and water-surface elevation) for the stream at a given location (AHPS forecast point) throughout the forecast period (every 6 hours and 3 to 5 days in the future in many locations). For more information on AHPS forecasts, please refer to http:// water.weather.gov/ahps/forecasts.php.

\section{Summary}

A series of five digital flood-inundation maps were developed in cooperation with the Indiana Department of Transportation for a 9.5-mile reach of the Patoka River in and near Jasper, southwestern Indiana (Ind.). The 9.5-mile study reach starts at the U.S. Geological Survey (USGS) streamgage, Patoka River at Jasper, Ind. (station 03375500) near County Road North 175 East, goes through the city of Jasper, and ends at State Road 162. The maps were developed using the U.S. Army Corps of Engineers' Hydrologic Engineering Center's River Analysis System (HEC-RAS) and HEC-GeoRAS programs to compute water-surface profiles and delineate estimated flood-inundation areas and depths of flooding for selected stream stages. The hydraulic model was calibrated to the stage-discharge relation (rating 36.0) at the Jasper streamgage and the documented high-water marks from the flood of April 30, 2017. The model was used to compute five water-surface profiles for flood stages referenced to the streamgage datum and ranging from 15 feet (ft), or near bankfull, to $19 \mathrm{ft}$. The stages from 15 to $19 \mathrm{ft}$ are equivalent to elevations from 460.22 to $464.22 \mathrm{ft}$ referenced to the North American Vertical Datum of 1988. The five simulated water-surface profiles were then combined with a geographic information system digital elevation model derived from light detection and ranging data to delineate estimated floodinundation areas as shapefile polygons and depth grids for each profile. These flood-inundation polygons were overlaid on high-resolution, geo-referenced, aerial photographs of the study area. The flood maps are available through a mapping application that can be accessed on the USGS Flood Inundation Mapping Science web site (https://water.usgs.gov/osw/ flood_inundation).

Interactive use of the maps on the USGS Flood-Inundation Mapper web application gives users a general indication of depth of water at any point by using the mouse cursor to click within the shaded areas. The mapping application enables the production of customized flood-inundation maps from the map library for the Patoka River in and near Jasper, Ind. These maps, in conjunction with the real-time stage data from the USGS streamgage, Patoka River at Jasper, Ind. (station number 03375500) will help to guide the general public in taking individual safety precautions and will provide 
emergency management personnel with a tool to efficiently manage emergency flood operations and postflood recovery efforts.

\section{References Cited}

Arcement, G.J., and Schneider, V.R., 1989, Guide for selecting Manning's roughness coefficients for natural channels and flood plains: U.S. Geological Survey Water-Supply Paper 2339, 38 p., accessed July 2017, at https://pubs.er.usgs.gov/ publication/wsp2339.

Dewberry, 2012, National enhanced elevation assessment final report: Fairfax, Virginia, Dewberry, 84 p., accessed July 2014, at http:/www.dewberry.com/services/geospatial/ national-enhanced-elevation-assessment.

Esri, 2014, About ArcGIS: Esri, accessed July 2014, at http:// www.esri.com/software/arcgis/.

Federal Emergency Management Agency (FEMA), 2014, Flood insurance study - Dubois County, Indiana and unincorporated areas: Washington, D.C., Federal Emergency Management Agency, 24 p., 12 pls.

Federal Emergency Management Agency (FEMA), 2017, National Flood Hazard Layer (NFHL), vector files and associated attributes, Dubois County: accessed February, 2017, at https://msc.fema.gov/portal/advanceSearch.

Flynn, K.M., Kirby, W.H., and Hummel, P.R., 2006, User's manual for program PeakFQ, annual flood-frequency analysis using bulletin 17B guidelines: U.S. Geological Survey Techniques and Methods, book 4, chap. B4, https://pubs. usgs.gov/tm/2006/tm4b4/\#title.

Fowler, K.K., 2018, Geospatial datasets and surface-water hydraulic model for the Patoka River at Jasper, Indiana, flood inundation study: U.S. Geological Survey data release, accessed November 2017, at https:// doi.org/10.5066/F7862DX0.

Gray, H.H., 2000, Physiographic divisions of Indiana: Bloomington, Indiana Geological Survey Special Report 61, 15 p., 1 pl., 2 figs.

Indiana Department of Natural Resources, 1976, Memorandum of understanding - Coordination of dischargefrequency determinations of Indiana streams: accessed February, 2017, at http://www.in.gov/dnr/water/files/waMemorandum_of_Understanding.pdf.
Indiana Department of Natural Resources, 2017, Coordinated discharges of selected streams in Indiana: Indiana Department of Natural Resources, accessed January 2017, at http:// www.in.gov/dnr/water/4898.htm.

Indiana University, 2013, Indiana spatial data portal: Indiana University database, accessed March 2015, at http://gis. iu.edu/.

Knipe, David, and Rao, A.R., 2005, FHWA/INJTRP-2005/1Estimation of peak discharges of Indiana streams by using log Pearson (III) distribution: accessed August 11, 2017, at: http://208.40.244.65/dnr/water/files/Estimation_of_Peak_ Discharges_of_Indiana_Streams.pdf.

National Weather Service, (NWS) 2017, Patoka River near Jasper, Indiana [JPRI3; USGS gaging station 03375500]: National Weather Service, Advanced Hydrologic Prediction Service, accessed January 2017, at http://water.weather.gov/ ahps $2 /$ hydrograph.php?wfo=ind\&gage=jpri3.

U.S. Army Corps of Engineers (USACE), 2011, HEC-GeoRAS - GIS tools for support of HEC-RAS using ArcGISUser's manual (ver. 43.93): U.S. Army Corps of Engineers, Hydrologic Engineering Center, [variously paged], accessed June 2014, at http://www.hec.usace.army.mil/software/hecgeoras/documentation/HEC-GeoRAS_43_Users_Manual. pdf.

U.S. Army Corps of Engineers (USACE), 2016, HEC-RAS river analysis system-Hydraulic reference manual (ver. 5.0.0): U.S. Army Corps of Engineers, Hydrologic Engineering Center, [variously paged], accessed February 14, 2017, at http://www.hec.usace.army.mil/software/hec-ras/ documentation/HEC-RAS\%205.0\%20Reference\%20Manual.pdf.

U.S. Census Bureau, 2010 Census interactive population search-IN-Jasper city: Washington, D.C., U.S. Census Bureau, accessed March 2017 at https://www.census. gov/2010census/popmap/ipmtext.php?fl=1837782.

U.S. Census Bureau, 2015, QuickFacts-Jasper city, Indiana; Dubois County, Indiana: Washington, D.C., U.S. Census Bureau, accessed March 2017, at https://www.census.gov/ quickfacts/table/HCN010212/1837782,18037.

U.S. Geological Survey (USGS), 2017a, Flood Inundation Mapping (FIM) Program: U.S. Geological Survey web site, accessed March 2017, at https://water.usgs.gov/osw/ flood inundation.

U.S. Geological Survey (USGS), 2017b, StreamStats in Indiana: U.S. Geological Survey StreamStats Program, accessed April 2017, at https://streamstats.usgs.gov/ss/. 
U.S. Geological Survey (USGS), 2017c, USGS 03375500

Patoka River at Jasper, IN-Current/historical observations: U.S. Geological Survey National Water Information System, accessed January 2017, at http://nwis.waterdata.usgs. gov/in/nwis/uv?site_no $=03375500$.

U.S. Geological Survey (USGS), 2017d, Peak streamflow for Indiana-USGS 03375500 Patoka River at Jasper, IN: U.S. Geological Survey National Water Information System, accessed March 2017, at http://nwis.waterdata. usgs.gov/in/nwis/peak?site_no=03375500\&agency_ $\mathrm{cd}=\mathrm{USGS} \&$ format $=\mathrm{html}$.

U.S. Geological Survey (USGS), 2017e, USGS 03375500 Patoka River at Jasper, IN-Summary of all available data: U.S. Geological Survey National Water Information System, accessed March 2017, at http://nwis.waterdata. usgs.gov/in/nwis/nwisman/?site_no=03375500\&agency_ $\mathrm{cd}=\mathrm{USGS}$.

Woolpert, Inc., 2011, Indiana statewide digital orthoimagery [metadata]: Indiana University, Woolpert Order No. 71177, prepared by Woolpert, Inc., Geospatial Services [Dayton, Ohio], accessed December 16, 2015, at http://gis.iu.edu/ files/documents/in2011_ortho.txt. 
For additional information, contact:

Director, Ohio-Kentucky-Indiana Water Science Center

U.S. Geological Survey

5957 Lakeside Boulevard, Indianapolis,

IN. 46278-1996

or visit our website at:

http://in.water.usgs.gov/

Prepared by USGS Madison and West Trenton Publishing Service Center 


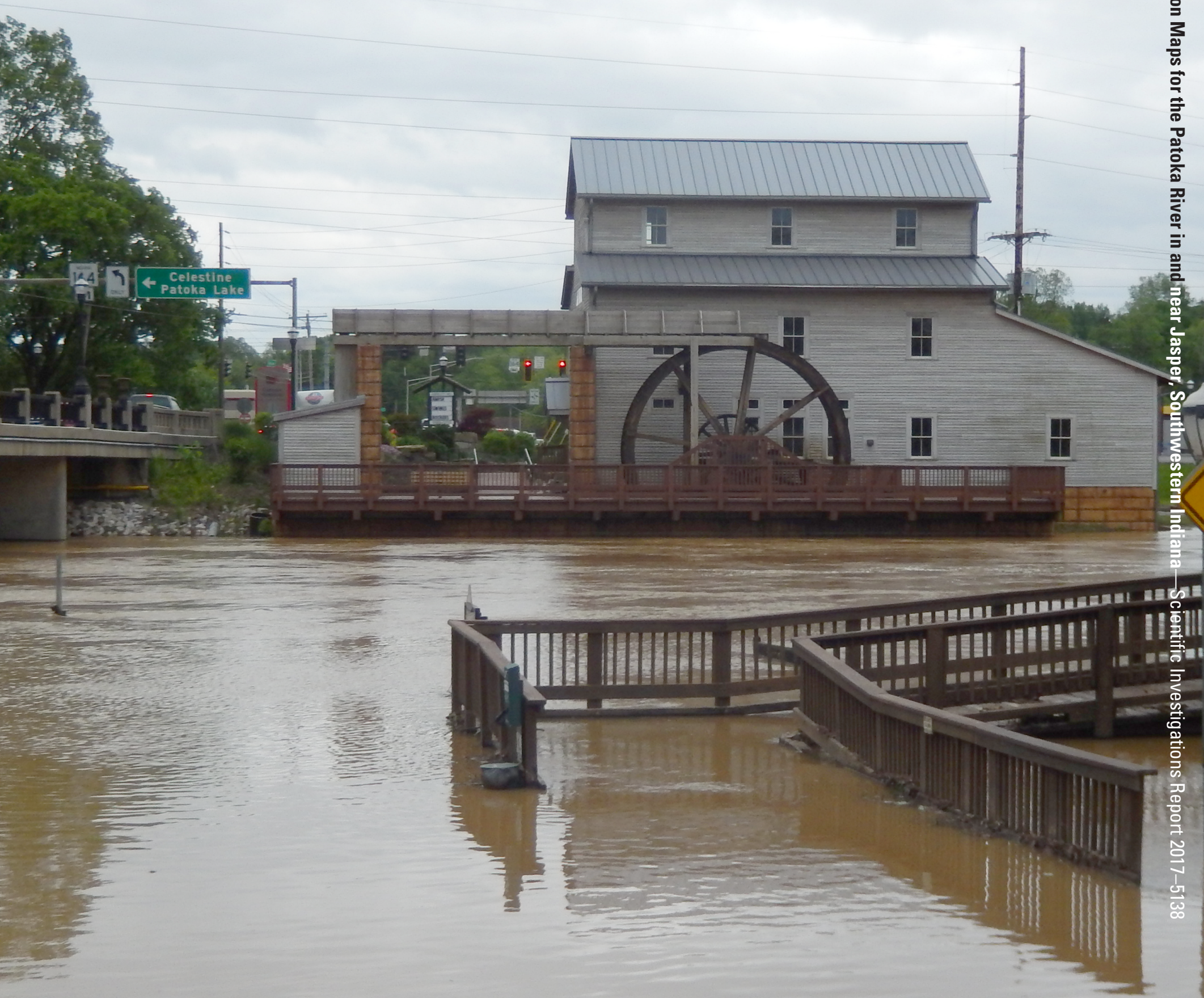

